\title{
Smart City Measurement: Identification of Smart Economy Performance Indicators in Indonesia
}

\author{
Bima Ajie Bahari ${ }^{1, *}$, Tony Dwi Susanto ${ }^{2}$, Janti Gunawan ${ }^{3}$ \\ ${ }^{I}$ Faculty of Intelligent Electrical and Informatics Technology, Institute Technology Sepuluh Nopember, Surabaya \\ Indonesia \\ ${ }^{2}$ Faculty of Intelligent Electrical and Informatics Technology, Institute Technology Sepuluh Nopember, Surabaya \\ Indonesia \\ ${ }^{3}$ Department of Business Management, Institute Technology Sepuluh Nopember, Surabaya, Indonesia
}

*Corresponding author.Email: bimaajiebahari@gmail.com

\begin{abstract}
The concept of smart city is believed to be one of the solutions to overcome problems in urban areas. Although much research has been carried out, there is still no agreed international standards regarding models, concepts, indicators, ways to measure smart city performance and the characteristics of each country that are different. In Indonesia, there is a smart city model that consists of 6 dimensions. One of the dimensions is smart economy, where there are three sub-dimensions to make it more specific and targeted. The three sub-dimensions are industry, welfare, and transactions. Also, there are factors of each subdimensions for support purpose. Smart economy has goal to develop competitive, superior, and adaptive economic ecosystems. This study aims to identify indicators of the application of the smart economy in Indonesia. Literature reviews related to smart economy will be used, and article sources come from leading online databases. The purpose of the literature review is to find indicators of other research findings outside Indonesia that are relevant to this study. Hundreds of articles have been found and filtered into 30 articles only. From 30 literatures, synthesis analysis was carried out to look for indicators of findings and mapped according to sub-dimensions and factors in Indonesia's smart economy. As a result, there are 18 indicators found. Indicators resulting from this research are expected to contribute both in theory and practice. In addition, the indicators found are expected to help the government develop smart cities in Indonesia.
\end{abstract}

Keywords: smart city, smart economy, smart economy indicator, indicator development.

\section{INTRODUCTION}

Smart cities have become a trend in recent decades as part of the strategic planning of a modern city [1]. The concept of smart city itself has existed since 30 years ago, along with the popularization of Information and Communication Technologies (ICT) [2]. The goal of smart city according to Schaffers (2011) [3] is to build sustainable economic growth and improve the quality of life of the community by utilizing human resources, social capital and modern technological infrastructure through government-based community participation.

The smart city idea cannot be separated from the increasing influence of urbanization [4]. It is estimated that by $2050,68 \%$ of the world's population will live in cities [5]. In Indonesia there will be approximately 148 million inhabitants out of 264 million total population living in urban areas on 2018 [5]. This dynamic will bring important changes in the role of a city, considering that the city is not only a center of human activity but also a 
great social and economic demand. Therefore urbanization can cause significant socio-economic changes and create new challenges for a country [4]. In Indonesia, smart city initiation has been started since 2017 through the "Movement Towards 100 Smart City" which is a program of several state institutions namely the Ministry of Communication and Information Technology (Kemkominfo), the Ministry of Home Affairs, the Ministry of PUPR, Bappenas and the Presidential Staff Office [6]. This movement aims to encourage and guide districts or cities in Indonesia to develop a master plan for the formation of smart cities in their respective regions to maximize the potential of available resources and technology [7]. In its implementation, there are 6 dimensions of smart city that must be met by the city or district participating in the "Movement Towards 100 smart cities". These dimensions are smart governance (smart governance), smart branding (smart regional branding), smart economy (smart economic governance), smart living (standard of living), smart society (smart society), and smart environment (smart environmental management) [8]. This research will focus on the smart economy dimension.

In the implementation of the "Movement Towards 100 smart cities" the Ministry of Communication and Information also conducted an evaluation. However, the evaluation only focused on the progress of smart city implementation carried out by the city/district, not how well the smart city implementation was carried out. Some institutions outside the government such as the Citiasia Center for Smart Nation (CCSN) have taken measurements related to the achievement of 7 categories, namely smart readiness, smart governance, smart branding, smart economy, smart living, smart society and smart environment to 98 cities and 412 districts in Indonesia [9]. Besides, there is also an assessment by Kompas Research and Development. The assessment is divided into 3 categories, namely economic, social, and environmental [10]. Although evaluations have been carried out from the government and outside the government, up to the time of this study, there were no official measuring standards that contain detailed indicators to measure how well the implementation of smart cities in cities/districts in Indonesia. Indicators are variables that can provide information about a particular condition so that it is possible to measure changes made over time [11]. Indicators play an important role in achieving effective, accurate, efficient, and responsive governance [12]. Besides, indicators are needed in measuring the process and performance of an activity carried out so that it can help achieve goals [13]. So that it takes a set of measuring devices, which include indicators of the achievement of the application of smart economy so that the implementation carried out by the city/district government can be successful as intended. This study aims to identify indicators of smart economy in the implementation of smart cities in Indonesia by conducting a review of the previous smart city research literature. This research is expected to help the government in developing and evaluating smart cities in Indonesia, especially in the smart economy dimension.

\section{LITERATURE REVIEW}

\section{Smart City}

Smart city is a concept that first appeared in 1998 by IBM [14]. The smart city is understood as an appropriate city development framework to overcome various problems in the city and as a tool to achieve transformation in social, economic, and environmental aspects [15]. The concept of smart city emerged along with the growth of urban society. A 2014 UN study on world urbanization trends showed 54\% of the human population lived in urban areas. This means that more than half of the human population lived in urban areas that year [16]. According to Schaffers (2011) [3] smart city has a definition of a city that is able to utilize human resources, social and cultural capital, and modern telecommunications infrastructure to realize sustainable economic stability and high quality of life for people through government-based participation in society. Meanwhile, according to Barrionuevo (2012) [17], smart city means using all available resources in a wise, smart, and coordinated way to develop a livable, integrated, and sustainable city.

\section{Smart Economy}

Smart economy in smart city aims to realize economic ecosystems in regions that are able to meet the challenges of the information age which are competitive, disruptive and demanding to adapt quickly [8]. The target of the smart economy dimension is an ecosystem that supports community economic activities that are aligned with leading and adaptive economic sectors to technological changes in this era and increase the financial iteracy of the community through various programs including cashless society. The target is realized by carrying out three elements in the smart economy, namely the industrial ecosystem, the improvement of people's welfare and the financial transaction ecosystem [8]. The economy of a city can be said to be "smart" if it can gather innovation and productivity to adapt to the market and the needs of workers to improve new business models and reliable global models so that they can compete on a local or global level [18]. Giffinger in his research entitled "Smart Cities Ranking of European medium-sized cities Final Report (2007)" mentions smart economy consists of various aspects such as entrepreneurship, productivity, employment, global competitiveness, the spirit of innovation and economic image/trademark. Giffinger divides smart economy into 
6 factors with 23 assessment indicators [19]. Smart economic governance is one of the dimensions that has an important role in the sustainability of activities and the welfare of the people in urban areas [20]. According to Bruneckiene \& Sinkiene (2014) [21] smart economy is one of the main keys and becomes a measurement tool for smart city implementation because urban areas have high economic competitiveness characteristics.

\section{Indonesia's Smart City}

In Indonesia, smart city initiation has been started since 2017 through the "Movement Towards 100 Smart City" which is a program of several state institutions namely the Ministry of Communication and Information Technology (Kemkominfo), the Ministry of Home Affairs, the Ministry of PUPR, Bappenas and the Presidential Staff Office [8]. The Movement Into 100 Smart City Program was officially launched in Makassar City in May 2017. In this program 25 cities/districts were selected as the smart city implementers in the first phase [6]. This movement aims to encourage and guide districts or cities in Indonesia to develop a master plan for the formation of smart cities in their respective regions with the aim of maximizing the potential of available resources and technology. In 2017, 25 cities / districts have been selected that are considered capable of implementing the concept of smart city. The city or district will be guided and accompanied directly by experts. This program targets that in 2019 there will be 100 cities / regencies in Indonesia that have implemented smart city-based development as well as being an example for other cities/regencies [6]. According to the RI Ministry of Communication and Information, there are 6 dimensions of smart city that must be met by the participating cities or regencies "Movement Towards

100 smart cities". These dimensions are smart governance, smart branding, smart economy, smart living, smart society, and smart environment.

Each dimension is not independent but rather integrated and influences one another [22]. One example is the initiative to empower MSMEs through a regional ecommerce program (smart economy) which will be influenced by the level of digital readiness of the community (smart society). In the implementation of the "Movement Towards 100 smart cities" the Ministry of Communication and Information also conducted an evaluation. However, the evaluation only focused on the progress of smart city implementation carried out by the city/district, not how well the smart city implementation was carried out. Some institutions outside the government such as the Citiasia Center for Smart Nation (CCSN) have taken measurements related to the achievement of 7 categories, namely smart readiness, smart governance, smart branding, smart economy, smart living, smart society and smart environment to 98 cities and 412 districts in Indonesia [9]. In addition, there is also an assessment by Kompas Research and Development. The assessment is divided into 3 categories, namely economic, social and environmental [10]. Although evaluations have been carried out from the government and outside the government, up to the time of this study there were no official measuring standards that contain detailed indicators to measure how well the implementation of smart cities in cities/districts in Indonesia.

\section{Smart City Measurement in Indonesia}

Measurement of the implementation of smart city in Indonesia has been carried out several times. One of the institutions that did the measurement was Kompas Research and Development, in which the Bandung Institute of Technology (ITB) was also involved. The measurement is called IKCI (Indonesian Smart Cities Index). A total of 93 cities/districts were ranked. The measurement is based on secondary data collected from several other institutions, one of which is BPS (Statistics Indonesia). There are 6 aspects that are used as indicators of assessment namely the environment, society, economy, mobility, government and quality of life. Cities assessed are divided into 4 categories namely metropolitan cities, large cities, medium cities and small cities [23].

Other assessments have also been carried out by the SCCIC (Smart City Community \& Innovation Center) ITB using the GSCF (Garuda Smart City Framework) framework. GSCF is a framework that focuses on smart city assessment with 3 aspects, namely economic, social and environmental. In addition there are also supporting aspects, namely technology, governance, and people. In total there are 111 assessment indicators with assessment results consisting of 5 levels. The levels from the lowest are adhoc, initiative, scattered, integrative and the highest is smart. Assessment with the GSCF has the aim to find out the extent of the readiness of a city / district in adopting the idea of smart city [24].

Based on some of the measurements that have been made, there are no details regarding the indicators used to assess. This makes it difficult for any local government to initiate smart city implementation. In the implementation of the "Movement Towards 100 Smart City" evaluation is conducted twice a year. Cities / regencies are required to complete data online from each question asked. In the assessment there are indicators in the form of general questions such as; Has the smart economy program been implemented this year? The question is final, so information about what steps must be taken to maximize value in each dimension is still lacking, especially in smart economy. 


\section{METHODOLOGY}

Previous studies that included smart city indicators, especially smart economy, have been scattered in several sources. Later these studies will be analyzed to identify which indicators are relevant to the research. The reference used in the context of smart economy in Indonesia is the "100 Smart City Movement Guidebook" where there are 3 sub-dimensions for smart economy, namely industry, welfare, and transaction. The method used in this study is a systematic review. A systematic review aims to identify, interpret, and evaluate the results of the previous article review so that it can be relevant to the research objectives [25]. Besides, a systematic review serves to explore gaps and inconsistencies in the literature so that new points or theories can be found [26].

\section{a. Data Collecting}

Literature review was conducted on previous research related to smart economy to identify the indicators needed. Previous research was obtained from reputable online publisher database such as sciencedirect.com, link.springer.com, ieeexplore.ieee.org, and emerald.com. The keywords used including; smart city, smart city indicators, smart economy, smart economy measurement, smart economy indicators, industry, welfare, cashless society, and other keywords related to the smart economy indicator. The indicators taken from previous studies are indicators that relate to Indonesia's smart economy subdimension. In addition, article searches are limited to the publication period from 2010 to 2020 .

The article sought must be relevant to the research topic and must be in English. Articles must be: in the form of research articles, not in the form of editorials, chapter books, working paper or opinions. In addition, the article must review economy in the city and its measurement, the article must produce indicators for smart economy, and finally, the indicators generated in the article can be grouped according to the smart sub-dimension in smart cities in Indonesia. More than a thousand articles found in the initial search. Further identification of the articles found in the initial search with inclusion and exclusion criteria. The results identified 30 articles that meet the criteria of inclusion.

\section{b. Data Mapping}

Indicators that have been collected from literature studies are then grouped by sub-dimensions of smart economy consisting of industry, welfare, and transactions [8]. From the Ministry of Communication and Information guidelines there are factors in the sub dimensions shown in the table 1 .
Table 1 Factors

\begin{tabular}{|c|c|c|}
\hline Industry & Welfare & Transaction \\
\hline $\begin{array}{c}\text { Industrial } \\
\text { competitiveness }\end{array}$ & $\begin{array}{c}\text { Income per } \\
\text { capita }\end{array}$ & $\begin{array}{c}\text { Less cash } \\
\text { society }\end{array}$ \\
\hline
\end{tabular}

Then synthesis analysis is done based on sub dimensions and existing factors. Aside from the smart economy dimension, the synthesis analysis also includes indicators from the general smart city research, because there are very few articles focusing on smart economy.

\section{RESULT AND DISCUSSION}

Based on the results of the analysis of synthesis 30 literature there are 20 smart economy indicators found. Indicators grouped based on smart economy subdimensions. Indicator result show in table 2.

Table 2 Smart Economy Indicators

\begin{tabular}{|l|l|l|}
\hline & Worker skill & $\begin{array}{l}\text { Network } \\
\text { availability }\end{array}$ \\
\hline & & $\begin{array}{l}\text { Market } \\
\text { intensity }\end{array}$ \\
\hline
\end{tabular}

In industry sub-dimension, industrial competitiveness aims to measure the ability of the industry to sell products that meet demand requirements such as quantity, quality and price and able to compete with competitors [28], [29], [30]. Meanwhile, industrial integration is related to the ability of industries to interconnect between sectors for the benefit of the country [28]. Export quality product is the ability to produce international quality goods [31], [32], [33].

In the welfare sub-dimensions Gross Domestic Product (GDP) is related to total value of market from all final goods and services produced [21], [28], [29], [32], [33], [34], [35], [36], [37], [38], [39], [40], [41], [42]. Household income measure the median of all people income in the same house [21], [28], [39], [41], [42], [43], [44]. Enterpreneurship growth is related to the number of businesses registered like micro and medium small businesses [21], [29], [30], [34],[36], [37], [39], [45], [46], [47], [48], [49],[50]. Percentageof unemployment is related to the rate of unemployment citizen in certain area [21], [28], [29], [30], [31], [32], [34],[35], [36], [38], [40], [41], [42], [43], [44], [47], [48], [50], [51]. Easy access to job information includes the level of ease of information 
through both print and digital media, job market and promotion [28], [29], [31], [46], [48], [52], Level of innovation and productivity is related to the ability of the community to produce work or businesses that have competitiveness [29], [30], [31], [35], [36], [41], [47], [48],[49], [50], [51]. Worker skill is related to related to the level of productivity to achieve valuable contributions to the company thereby increasing revenue [28], [41], [53].

In transaction sub-dimension "lesh cash" machine availability measure about the quantity, readiness and human support about the machine (ATM) [28], [29], [46], [48], [52]. Less cash knowledge measure how good the citizen knowledge about cashless system [28], [41], [53]. Bankable society is is the level of customer eligibility that meets bank requirements [21], [28], [38], [41], [50], [52]. Fintech quality refers to how good the technology is in supporting transactions conducted by citizens [21], [28], [29], [46]. Foreign direct and domestic invesment is related to level of investment from abroad directly to domestic companies [32], [37], [40], [53], [54], [55]. Network availability refers to refers to the availability of IT equipment, internet networks and the ability of the community to operate technology [28], [29], [31], [46], [48], [52]. Finally, market intensity is the frequency of spending through e-commerce, the number of sellers in the market place and product availability [21], [29], [31], [35],[45], [49], [51].

\section{CONCLUSION}

Smart economy becomes one of the dimensions in Smart City because in the information age as it is today, economic movement is an essential key in the progress of a city. Still, it must also be able to attract community participation from both inside and outside the city, as well as business people and investors, to help accelerate urban development. Smart economy is an innovative and creative practice of the city government. The aim is to realize the economic ecosystem in regions that can meet the challenges of the information age, which are competitive, disruptive, and demanding to adapt quickly. Previous research shows that GDP per capita and unemployment rate are aspects of crucial in smart economy activities. This situation is identified from the number of indicators in the welfare sub- dimension. Besides, all previous studies in this study showed the effect of income on cities' economies. Indicators result is expected to contribute to the development of smart city implementation in Indonesia both in theory and practice. Future studies are expected to be able to find other indicators related to Indonesia's smart economy's characteristics and look for factors that inhibit the development of smart economy also suggested.

\section{REFERENCES}

[1] Amine, T. M., Abderrahman, D., R. Z. \& Mohamed, A., 2016. Smart cities and new technology trends: state of the art and perspectives. International Journal on Recent and Innovation Trends in Computing and Communication, 4(7), pp. 282-285

[2] Caragliu, A., Bo, C. D. \& Nijkamp, P., 2011. Smart cities in Europe. Journal of Urban Technology, 18(2), pp. 65-82

[3] Schaffers, H. et al., 2011. Smart cities and the future internet: towards cooperation frameworks for open innovation. s.1., s.n., pp. 431-446.

[4] ChuanTao, Y., Zhang, X., Hui, C. \& JingYuan, W., 2015. A literature survey on smart cities. SCIENCE CHINA Information Science.

[5] Ritchie, H. \& Roser, M., 2019. ourworldindata.org/urbanization. [Online] Available at: https://ourworldindata.org/urbanization

[6] Rizkinaswara, L., 2018. [Online] Available at:https://aptika.kominfo.go.id/2018/11/gerakanmenuju- 100-smart-city/[Accessed $10 \quad 05$ 2020]Rosandya, R., 2017. Neraca. [Online] Available at: https://kominfo.go.id/content/detail/11656/langka h-menuju-100-smart-city/0/sorotan_media [Accessed 1005 2020]

[7] Kemkominfo, 2017. Buku Panduan Penyusunan Master Plan Smart City 2017 Gerakan Menuju Smart City. 1st Edition ed. s.1.:s.n

[8] Smartnation.id, 2018. Inilah Para Penerima Penghargaan The 3rd ISNA 2018. [Online] Available at: https://smartnation.id/2018/05/05/inilah- parapenerima-penghargaan-the-3rd-isna-2018/

[9] surabaya.go.id, 2019. Penghargaan Indeks Kota Cerdas Indonesia (IKCI) Diraih Surabaya. [Online] Available at: https://surabaya.go.id/id/berita/50028/penghargaa n- indeks-kota-cerdas

[10] Bosch, P. \& Gabrielsen, P., 2003. Environmental indicators: typology and use in reporting. s.l.:s.n

[11] G.Manasan, R., Gaffud, R. \& T.Gonzales, E., 1999. Indicators of good governance: developing an index of governance quality at the LGU level. Philippine Journal of Development, February, 26(2), pp. 1-69.

[12] Velimirović, D., Velimirović, M. \& Stanković, R., 2011. Role and importance of key performance indicators measurement. Serbian Journal of Management, Volume 6, pp. 63-72.

[13] Bollier, D., 1998. How smart growth can stop sprawl - a fledgling citizen movement expands / a briefing guide for funders 1998. 1st Edition ed. 
Washington DC: Essential Books

[14] Djunaedi, A. et al., 2018. Membangun Kota dan Kabupaten Cerdas: Sebuah Panduan bagi Pemerintah Daerah. 1st Edition ed. Yogyakarta: UGM Press

[15] Albino, V., Berardi, U. \& Dangelico, R. M., 2015. Smart cities: definitions, dimensions, performance, and initiatives. Journal of Urban Technology, 22(1), pp. $1-19$

[16] Barrionuevo, J. M., Pascual, B. \& Eric, R. J., 2012. Smart Cities, Sustainable Progress: Opportunities for Urban Development. IESE Insight, 15 September, Volume 14, pp. 50-57

[17] Monzon, A. et al., 2017. Assessment Methodology for Smart City Projects: Application to the Mediterranean Region, Madrid: Ascimer

[18] Giffinger, 2007. Smart cities ranking of European medium-sized cities, Vienna: the Centre of Regional Science 2010, pp. 133-142.

[19] Tyas, W. P., 2019. Applying smart economy of smart cities in developing world: learnt from indonesia's home based enterprises. s.l., s.n.

[20] Dagiliene, L., Bruneckiene, J., Jucevicius, R. \& Lukauskas, M., 2019. Exploring smart economic development and competitiveness in Central and Eastern European countries. An International Business Journal, Volume In Press, pp. 1-21.

[21] Susanto, T. D., 2019. SMART CITY: DEFINISI, MODEL, \& DIMENSI. In: SMART CITY: KONSEP, MODEL, \& TEKNOLOGI. Surabaya: Asosiasi Sistem Informasi Indonesia (AISINDO), pp. 2-3.

[22] Publik, B. I., 2019. Pemerintah Kota Malang.[Online] Available at: https://malangkota.go.id/2019/01/10/kotamalang-raih-penghargaan-ikci2018/?utm_source=dlvr.it\&utm_medium=facebo ok [Accessed 0506 2020]

[23] Irawan, I., 2018. sccic.id. [Online] Available at: https://www.sccic.id/research/garuda- smartcity-model/-346

[24] Kitchenham, B., 2004. Procedures for Performing Systematic Reviews, s.l.: NICTA Technical Report

[25] Vet, H. d., Verhagen, A., Logghe, I. \& Ostelo, R., 2005. Literature research: Aims and design of systematic reviews. Australian Journal of Physiotherapy, Volume 51, pp. 125-128.

[26] Allam, Z. \& Newman, P., 2018. Redefining the smart city: culture, metabolism and governance. Smart Cities, 1(1), pp. 4-25

[27] Lombardi, P., Giordano, S., Farouh, H. \& Yousef, W., 2012. Modelling the smart city performance. The European Journal of Social Science Research, Volume 25, pp. 137-149.

[28] Sharifi, A., 2020. A typology of smart city assessment tools and indicator sets. Sustainable Cities and Society, Volume 53, pp. 1-36.

[29] Sharifi, A., 2019. A critical review of selected smart city assessment tools and indicator sets. Journal of Cleaner Production, Volume 233, pp. 1269-1283.

[30] Akande, A., Cabral, P., Gomes, P. \& Casteleyn, S., 2019. The Lisbon ranking for smart sustainable cities in Europe. Sustainable Cities and Society, Volume 44, pp. 475-487.

[32] Li, X., Fong, P. S., Dai, S. \& Li, Y., 2019. Towards sustainable smart cities: An empirical comparative assessment and development pattern optimization in China. Journal of Cleaner Production, Volume 215, pp. 730-743.

[33] Falco, S. D., 2019. Are smart cities global cities? A European perspective. European Planning Studies, 27(4), pp. 759-783.

[34] Marchetti, D., Oliveira, R. \& Figueira, A. R., 2019. Are global north smart city models capable to assess Latin American cities? A model and indicators for a new context. Cities, Volume 92, pp. 197-207.

[35] Huovila, A., Bosch, P. \& Airaksinen, M., 2019. Comparative analysis of standardized indicators for Smart sustainable cities: What indicators and standards to use and when?. Cities, Volume 89, pp. 141-153.

[36] Shen, L. et al., 2018. A holistic evaluation of smart city performance in the context of China. Journal of Cleaner Production, Volume 200, pp. 1-53.

[37] Sureshchandra, S. M., Bhavsar, J. J. \& Pitroda, J. R., 2016. Assesment of critical success factors for smart cities using significance index method. International Journal of Advance Research and Innovative Ideas in Education, 2(3), pp. 802-810.

[38] Ahvenniemi, H., Huovila, A., Pinto-Seppä, I. \& Airaksinen, M., 2017. What are the differences between sustainable and smart cities?. Cities, Volume 60, pp. 234-245.

[39] Loo, B. P. Y. \& Tang, W. S. M., 2019. "Mapping" Smart Cities. Journal of Urban Technology, 26(2), pp. 129-146.

[40] Warnecke, D., Wittstock, R. \& Teuteberg, F., 2019. Benchmarking of European smart cities - a maturity model and web-based self-assessment tool. Sustainability Accounting, Management and Policy Journal, 10(4), pp. 654-684.

[41] Dudzevičiūtè, G., Šimelytė, A. \& Liučvaitienè, A., 2017. The application of smart cities concept for citizens of Lithuania and Sweden: comperative analysis. Independent Journal of Management \& Production, 8(4), pp. 1433-1450.

[42] Goodman, N., Zwick, A., Spicer, Z. \& Carlsen, N., 2020. Public engagement in smart city development: lessons from communities in 
Canada's smart city challenge. The Canadian Geographer, pp. 1-17.

[43] Tania Ray Bhattacharya, A. B., Mclellan, B. \& Tezuka, T., 2018. Sustainable smart city development framework for developing countries. Urban Research \& Practice, Volume 13, pp. 180212.

[44] Lazaroiu, G. C. \& Roscia, M., 2012. Definition methodology for the smart cities model. Energy, Volume 47, pp. 326-332.

[45] Ismagilova, E., Hughes, L., Dwivedi, Y. K. \& Raman, K. R., 2019. Smart cities: Advances in research-An information systems perspective. International Journal of Information Management, Volume 47, pp. 88-100.

[46] Anthony, B., 2020. A case-based reasoning recommender system for sustainable smart city development. AI\&SOCIETY, pp. 1-25.

[47] Giffinger, R., Haindlmaier, G. \& Kramar, H., 2010. The role of rankings in growing city competition. Urban Research and Practice, 3(3), pp. 299-312.

[48] Neirotti, P. et al., 2014. Current trends in Smart City initiatives: Some stylised facts. Cities, Volume 38, pp. 25-36.

[49] Appio, F. P., Lima, M. \& Paroutis, S., 2019. Understanding Smart Cities: Innovation ecosystems, technological advancements, and societal challenges. Technological Forecasting and Social Change, Volume 142, pp. 1-14.

[50] Galperina, L. P., Girenko, A. T. \& Mazurenko, V. P., 2016. The concept of smart economy as the basis for sustainable development of Ukraine. International Journal of Economics and Financial Issues, Volume 6, pp. 307-314.

[51] Schiavone, F., Paolone, F. \& Mancini, D., 2019. Business model innovation for urban smartization. Business model innovation for urban smartization, Volume 142, pp. 210-219.

[52] Al-Alwani, M. K., 2018. A development framework for smart cities assessment. Journal of University of Babylon, 26(3), pp. 340-349.

[53] Heaton, J. \& Parlikad, A. K., 2019. A conceptual framework for the alignment of infrastructure assets to citizenrequirements within a Smart Cities framework. Cities, Volume 90, pp. 32-41.

[54] Yadav, G., Mangla, S. K., Luthra, S. \& Rai, D. P., 2019. Developing a sustainable smart city framework for developing economies: An Indian context. Sustainable Cities and Society, Volume 47, pp. 1-14.

[55] Mattoni, B., L.Pompei, Losilla, J. \& Bisegna, F., 2020. Planning Smart cities: comparison of two quantitative multicriteria methods applied to real case studies. Sustainable Cities and Society, Volume 60 